Research Article

\title{
p53 Gene Codon 72 Polymorphisms among Cervical Carcinoma Patients
}

\author{
Polimorfisme Gen p53 Kodon 72 pada Penderita Karsinoma Serviks yang Dirawat \\ Rustham Basyar ${ }^{1}$, Agustria Z Saleh ${ }^{1}$, Irawan Sastradinata ${ }^{1}$, Yuwono ${ }^{2}$ \\ ${ }^{1}$ Department of Obstetrics and Gynecology \\ ${ }^{2}$ Department of Microbiology \\ Faculty of Medicine University of Sriwijayal \\ Dr. Mohammad Hoesin General Hospital \\ Palembang
}

\begin{abstract}
Objective: To identify the association between p53 gene codon 72 polymorphism and cervical carcinoma.

Method: An analytic observational study with case-control design, from November 2013 until March 2014 in the Department of Obstetrics and Gynecology and Microbiology Laboratory Faculty of Medicine, Sriwijaya University, Dr. Moh. Hoesin Hospital Palembang.

Result: In total there are 100 samples analyzed consisting of 50 subjects and 50 control groups. Genotype distribution in subject group are $54 \% \mathrm{Arg} / \mathrm{Arg}, 42 \%$ Pro/Arg and $4 \%$ Pro/Pro, and in control group are 36\% Arg/Arg, 46\% Pro/Arg and 18\% Pro/Pro. Arg/Arg genotype is at risk of cervical carcinoma 6.7 times higher compared with Pro/Pro genotype ( $p=0.013$; OR 6.75; 95\% CI 1.34-34.94). Arg allele in the p53 gene codon 72 increase the risk of cervical carcinoma 2.6 times more than Pro allele.

Conclusion: Proline mutation to Arginine in gene p53 P72R is one of the risk factor for cervical carcinoma.
\end{abstract}

[Indones J Obstet Gynecol 2015; 3: 165-169]

Keywords: arginine, cervical carcinoma, gene p 53 codon 72 , polymorphism, proline

\begin{abstract}
Abstrak
Tujuan: Mengetahui bubungan antara polimorfisme gen p 53 kodon 72 dan karsinoma serviks.

Metode: Penelitian observasional analitik dengan desain studi kasuskontrol. Dilakukan dari November 2013 sampai dengan Maret 2014 bertempat di Departemen Obstetri dan Ginekologi Rumah Sakit Dr. Mohammad Hoesin Palembang dan Laboratorium Mikrobiologi Rumab Sakit Dr. Moh. Hoesin Palembang.

Hasil: Penelitian diikuti oleb 100 subjek yang memenubi kriteria inklusi, masing-masing 50 subjek pada kelompok kasus dan kontrol. Distribusi genotipe gen p 53 kodon 72 pada kelompok kasus adalah Arg/Arg $54 \%$, Pro/Arg 42\% dan Pro/Pro 4\% sedangkan pada kelompok kontrol Arg/Arg $36 \%$, Pro/Arg 46\% dan Pro/Pro 18\%. Genotip Arg/Arg memiliki risiko 6,7 kali lebib besar untuk terjadi karsinoma serviks dibandingkan dengan genotip Pro/Pro. Adanya alel Arg pada gen p53 kodon 72 meningkatkan risiko terjadinya karsinoma serviks 2,6 kali lebih besar dibandingkan alel Pro.

Kesimpulan: Mutan Prolin menjadi Arginin pada polimorfisme gen $p 53$ $P 72 R$ merupakan faktor risiko terjadinya karsinoma serviks.

[Maj Obstet Ginekol Indones 2015; 3: 165-169]

Kata kunci: arginin, gen p 53 kodon 72, karsinoma serviks, polimorfisme, prolin
\end{abstract}

Correspondence: Rustham Basyar. Obstetrics and Gynecology Department. Faculty of Medicine, Sriwijaya University Palembang. Email: rbasyar@gmail.com

\section{INTRODUCTION}

Cervical carcinoma is the most common gynecological malignancy and the second most common malignancies in women worldwide. Data from the Department of Anatomical Pathology Faculty Of Medicine, Sriwijaya University RSMH Palembang also places cervical carcinoma as the second most common malignancy in women, after breast malignancy. ${ }^{1-4}$

Although the role of HPV in cervical cancer carcinogenesis has been proven, only a few of HPV infection will develop into cervical carcinoma. This suggests possibility of other influences that might be involved in the development of cervical carcinoma, one of them is genetic factor. Mutation of the p53 gene is one of the genetic variations associated with the occurrence of malignancy. ${ }^{5-7}$

P53 gene is a tumor suppressor gene that plays a role in response to stress in order to maintain genomic stability, responds to DNA damage, hypoxia, metabolic stress and activation of oncogenes. Single nucleotide polymorphisms (SNPs) of p53 gene codon 72 will produce two types of alleles, namely Arginine (p53-R72) or Proline (p53-P72) at the structure of the amino acid at codon 72. According to Storey, women who are homozygous for Arginine at codon 72 of p53 gene are seven times more likely to be exposed to cervical cancer.6,9-11 
Comparative sequence analysis of non-human primates demonstrated that $\mathrm{p} 53-\mathrm{P} 72$ is the wild type, although the number of $\mathrm{p} 53-\mathrm{R} 72$ population is quite enough $(>50 \%)$. The frequency of homozygous Arginine in certain ethnicity is between $12.4 \%$ and $53.4 \%$. Beckman and his colleagues were the first to demonstrate the difference in allele frequency distribution between the R72 and P72 in Nigerian population (black Africans) and Sweden (Europe West), amounting 17 percents and 63 percents of the population. $6,9,11-12$

Variation of the allele frequency in some ethnicities may cause differences in research result about relationship between $\mathrm{p} 53$ codon 72 polymorphism and cervical carcinoma in several countries. Research in Sweden, Chile, Peru, China and India supported these findings. 5,8,13-16 However, studies in Netherlands, USA, Poland, Italy, Korea, Japan and Thailand are contradictory. ${ }^{17-26}$ In Palembang, there is no data about codon 72 allele of the p53 gene and its association with carcinoma of the cervix, so it is necessary to identify the association between p53 codon 72 polymorphism and cervical carcinoma in Palembang population.

\section{METHOD}

This is an analytical observational research with case control study design. This study is conducted at the Department of Obstetrics and Gynecology and Microbiology Laboratory of Faculty of Medicine Sriwijaya University in Dr. Mohammad Hoesin Hospital Palembang, which started from November $1^{\text {st }}$ 2013 until March 31 2014.

Populations of this study are patients who are diagnosed with cervical carcinoma who came to the outpatient clinic and any hospitalized patient in obstetric and gynecology department of RSMH Palembang. Sampling is done by quota sampling technique, until total subjects in the experimental group and control group reach 50 patients.

The inclusion criteria for the experimental group are patients who are diagnosed with cervical carcinoma, which is proved by histopathology result and patient's willingness to join the research by signing the informed consent form. For the control group, inclusion criteria are patients who came to gynecology outpatient clinic or who has been hospitalized in in-patient installation of obstetric and gynecology department of RSMH Palembang who is not diagnosed or suspected to have neoplasm or another malignancy diseases, no precancerous lesion Pap Smear examination or suspected to have cervical carcinoma and patient's willingness to join the research by signing the informed consent form.

Exclusion criteria for case group are patients who have been diagnosed or suspected to have other malignancy or if patient are not willing to join the research. For the control group, criteria were precancerous lesion in Pap's Smear result or suspected cervical carcinoma patients who refuse to join the research.

\section{RESULT}

Table 1 shows the socio-demographic and clinical characteristic of research subjects.

Table 1. Socio-demographic and Clinical Characteristic.

\begin{tabular}{|c|c|c|c|}
\hline Characteristic & Case & Control & $\mathrm{p}$ \\
\hline Median age & $49 \pm 8.8$ & $38.8 \pm 9.5$ & $<0.0001$ \\
\hline Median BMI & $23.22 \pm 4.90$ & $21.64 \pm 31.08$ & 0.058 \\
\hline \multicolumn{4}{|l|}{ Domicile } \\
\hline Urban area & 31 & 41 & 0.03 \\
\hline Rural area & 19 & 9 & \\
\hline \multicolumn{4}{|l|}{ Ethnic group } \\
\hline Sumatera & 33 & 42 & 0.038 \\
\hline Non-Sumatera & 17 & 8 & \\
\hline \multicolumn{4}{|l|}{ Education } \\
\hline Uneducated & 5 & 0 & $<0.0001$ \\
\hline Elementary & 14 & 1 & \\
\hline Junior high & 14 & 6 & \\
\hline Senior high & 16 & 22 & \\
\hline Bachelor & 1 & 21 & \\
\hline \multicolumn{4}{|l|}{ Occupation } \\
\hline Housewife & 38 & 22 & $<0.0001$ \\
\hline Civil servant & 1 & 27 & \\
\hline Others & 11 & 1 & \\
\hline \multicolumn{4}{|l|}{ Smoking history } \\
\hline Yes & 2 & 2 & 1.00 \\
\hline No & 48 & 48 & \\
\hline \multicolumn{4}{|l|}{$\begin{array}{l}\text { Contraception } \\
\text { history Oral }\end{array}$} \\
\hline Yes & 9 & 4 & 0.23 \\
\hline No & 41 & 46 & \\
\hline \multicolumn{4}{|l|}{ First sexual activity } \\
\hline$<20$ years old & 33 & 8 & $<0.001$ \\
\hline$\geq 20$ years old & 17 & 42 & \\
\hline \multicolumn{4}{|l|}{ Marriage history } \\
\hline 1 time & 6 & 2 & 0.27 \\
\hline$>1$ time & 44 & 48 & \\
\hline \multicolumn{4}{|l|}{ Parity total } \\
\hline$\geq 7$ & 8 & 0 & $<0.001$ \\
\hline$<7$ & 42 & 50 & \\
\hline
\end{tabular}


The youngest age in this research is 19 years old and the oldest subject is 73 years old. There is a significant difference in median age, domicile distribution, ethnic group and occupation between the case and control group.

Age of first sexual activity and total parity are important clinical risk factors for cervical carcinoma. However smoking, oral contraception, and marriage status showed no significant correlation with the incidence of cervical carcinoma. The clinical characteristics of the research subjects are presented on the table above.

In this research gene p53 codon 72 is obtained through DNA extraction process and PCR-RFLP method from blood sample. Polymorphism in gene p53 codon 72 is recognized with BstUI enzyme. Figure 1 showing the PCR-RFLP result example. Genotype appearance of wild type Pro/Pro (1 band with fragment length $199 \mathrm{bp}$ ) is showed in subject number 46. Subject number 50 has mutant genotype Arg/Arg (2 bands with fragment length $113 \mathrm{bp}$ and 86 bp). Subject number 47, 48 and 49 exhibit mutant heterozygote genotype appearance of Pro/Arg (3 bands with fragment lengths of $199 \mathrm{bp}, 113 \mathrm{bp}$ and $86 \mathrm{bp})$.

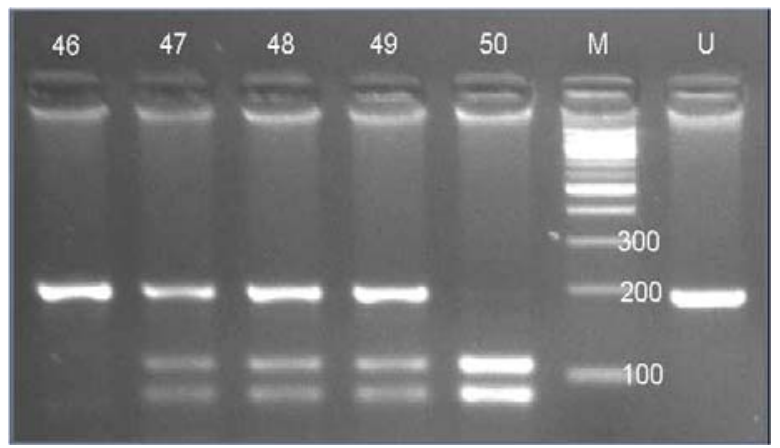

Figure 1. Example of PCR-RFLP Result Gene p53 Codon 72 with BstUI Restriction Enzyme.

Genotype distribution in case group is Arg/Arg 54\%, Pro/Arg 42\% and Pro/Pro 4\%. The distribution of genotype in control group is Arg/Arg 36\%, Pro/Arg 46\% and Pro/Pro 18\%. In general, the distribution of genotype Arg/Arg, Pro/Arg and Pro/Pro are $45 \%, 44 \%$ and $11 \%$ respectively. From the whole subjects, Arg allele percentage is $67 \%$ and Pro allele is $33 \%$.

Statistic analysis with Chi square test is done to determine the correlation between polymorphism gene p53 codon 72 and cervical carcinoma. There is a significant increase in the risk of cervical carci- noma for individual with homozygote mutant genotype (Arg/Arg) compared with individual with wild type genotype (Pro/Pro) on gene p53 codon 72 $(\mathrm{p}=0.013$; OR $6.75 ; 95 \%$ CI 1.34-34.94). Allele analysis showed women who has Arginine allele in the p53 gene codon 72 is at risk of cervical cancer 2,6 times greater than women with Proline allele (OR 2.61; 95\% CI 1.40-4.88).

Table 2. Correlation of Genotype p53 Gene Codon 72 and Carcinoma Cervix

\begin{tabular}{|c|c|c|c|c|c|c|}
\hline & & \multicolumn{2}{|c|}{ Case } & \multicolumn{2}{|c|}{ Control } & \multirow{2}{*}{ p } \\
\hline & & $\mathrm{N}$ & $\%$ & $\mathbf{N}$ & $\%$ & \\
\hline \multirow[t]{3}{*}{ Genotype } & Arg/Arg & 27 & 54 & 18 & 36 & $0.013 *$ \\
\hline & Pro/Arg & 21 & 42 & 23 & 46 & $0.097 * *$ \\
\hline & Pro/Pro & 2 & 4 & 9 & 18 & Ref \\
\hline \multicolumn{2}{|c|}{ Total } & 29 & 100 & 27 & 100 & \\
\hline
\end{tabular}

\section{DISCUSSION}

Epidemiological data shows that most cervical carcinoma is found in young women. Median age of this finding is 52 years old with distribution peak at age of 35-39 years old and 60-64 years old.1,3 Concurrent with previous literature, median age of the case group (cervical carcinoma) in this research is $49.8 \pm 8.8$ years old.

In this research, there is a significant difference in domicile, education level, job and ethnic group between case group and control group. Whereas median body mass index (BMI) in this research subject found no differences between both groups. Socioeconomic factor is related with carcinoma cervix. The majority of carcinoma cervix patients came from low socioeconomic who has no access to routine gynecology examination. ${ }^{1,3}$ Reis et al discovered that individual with high education level has lower risk of cervical carcinoma(OR 0.18). They suggested that low education level is related with an increase of sexual activity on young age, numerous sexual partners and bad genital hygiene. ${ }^{27}$

Statistically in this research there is no significant correlation between smoking history and cervical carcinoma. This result is different with meta-analysis about correlation between smoking and cervical carcinoma by Gandini et all. They concluded that active smokers are at increased risk of contracting cervical squamous cell carcinoma (RR 2.03; 95\% CI 1.31-4.04), whereas risk among ex-smoker is relatively lower at 1.80 (95\% CI 0.95-3.44). ${ }^{28}$ 
Reproductive history is also affects the risk of cervical carcinoma. Analysis result in this research also shows significant correlation between parity $\geq 7$ and cervical carcinoma $(p=0.006)$. Women who has parity $\geq 7$ times has 2 times the risk to have carcinoma cervix (OR 2.19; 95\% CI 1.75-2.74).

Median age of first sexual activity in the case group in this research is $19.12 \pm 3.98$ years old. This median age is lower than the control group. Statistical analysis shows an increased risk of cervical carcinoma 10 times higher than women who have their first sexual activity before the age of 20 is 10.19 (95\% CI 3.92-26.51).

Oral contraception combination pill usage can be a risk factor of cervical carcinoma. Research from Moreno et all show an odds ratio of 2.82 (95\% CI 1.46-5.42) for contraception usage 5-9 years and 4.03 (95\% CI 2.09-8.02) for usage $\geq 10$ years. $1,3,27,29,30$ However in this research, there is no significant correlation between oral contraception and cervical carcinoma $(p=0.23)$.

Comparative sequence analysis to primate except human shows that p53-R72 is a wild type, even though p53-R72 in population is varied $(>50 \%)$. Data from various ethnicities shows Arginine homozygous frequency is between $12.4 \%$ till $53.4 \% .6,9,27,31$ Genotype distribution pattern and allele in this research is similar with Andersson's research in Sweden and Ojeda's in Chile; the only difference is the lower genotype distribution of wild type. ${ }^{5,13}$

Chi square test done between gene genotype p53 codon 72 and cervical carcinoma concludes that there is an increasing risk of cervical carcinoma 6.7 times for individual with homozygote mutant genotype (Arg/Arg) compared with individual with wild type genotype (Pro/Pro) for gene p53 codon 72 (OR 6.75; 95\% CI 1.34-34.94). Individuals with heterozygote mutant genotype (Pro/Arg) have no significant risk when compared with women with wild type genotype $(p=0.079)$. Allele analysis shows significant result for allele Arg to p53 gene codon 72, which will increase the risk of carcinoma cervix 2.61 times higher than allele Pro ( $p=0.02$; OR 2.61; 95\% CI 1.40-4.88).

Some of supporting researches have various odds ratio (OR) result. Meta-analysis by Jee et al in 2004 shows that the odds ratio (OR) of women with cervical carcinoma with homozygote mutant (Arg/ Arg) compared with heterozygote mutant (Arg/ Pro) in general is $1.2(1.1-1.3 ; \mathrm{p}<0.001) .{ }^{32}$
Some of the researches also relates polymorphism p53 codon 72 with prognosis and response to therapy. Individual with genotype R72 has a higher risk and better quality of life after receiving chemotherapy or radiation therapy. Similar results are also found in cancer of head and neck, breast and lung. ${ }^{9}$

\section{CONCLUSION}

Proline mutation to Arginine in gene $\mathrm{p} 53 \mathrm{P} 72 \mathrm{R}$ is a risk factor for cervical carcinoma.

\section{REFERENCES}

1. Schorge JO, Hoffman B, Scaffer J, et al. eds. Williams gynecology. New York: McGraw-Hill; 2008.

2. Cho KR. Cervical cancer. In: Vogelstein B, Kinzler KW (eds). The genetics basis of human cancer. New York: McGraw-Hill; 2002: 689-95.

3. Giuntoli RLH, Bristow RE. Cervical cancer. In: Gibbs RS, Karlen BY (eds). Danforth's obstetrics and gynecology. Philadelphia: Lippincott Williams and Wilkins; 2008: 971-3

4. Departemen Patologi Anatomi Rumah Sakit Moehammad Hoesin. Rekapitulasi temuan kasus kanker tahun 2007-2009. Palembang, 2010.

5. Andersson S, Rylander E, Strand A, et al. The significance of p53 codon 72 polymorphism for the development of cervical adenocarcinomas. Brit J Cancer 2001; 85(8): 1153-6.

6. Tommasino M, Accardi R, Caldeira S, et al. The role of TP53 in cervical carsinogenesis. Hum Mutat 2003; 21: 307-12.

7. Feng Q, Jiang M, Deftereos G, et al. Human Papillomavirus and its role in cervical carsinogenesis. In: Molecular diagnostics: techniques and applications for clinically laboratory. Acad Press; 2010: 301-12.

8. Jiang P, Liu J, Li W, et al. Role of p53 and p21 polymorphism in the risk of cervical cancer among Chinese women. Act Biochem Biophys Sin 2010; 42: 671-6.

9. Pietsch EC, Humbey O, Murphy ME. Polymorphism in the p53 pathway. Oncogene 2006; 25: 1602-11.

10. Siddique MM, Balram C, Aggarwal A, et al. Evidence for selective expression of the p53 codon 72 polymorphs; implications in cancer development. Cancer Epidemiol Biomarkers Prev 2005; 14(9): 2245-52.

11. Storey A, Thomas M, Kalita A, et al. Role of a p53 polymorphism in the development of human papilloma-virusassociated cancer. Nature 1998; 393: 229-37.

12. Whibley C, Pharoah, PD, Hollstein M. p53 polymorphism: cancer implications. Nature Rev 2009; 9: 95-107.

13. Ojeda JM. p53 codon polymorphism and risk of cervical cancer. Biol Res 2003; 36: 279-83.

14. Zehbe I, Voglino G, Wilander E, et al. p53 codon 72 polymorphism and various human papillomavirus $16 \mathrm{E} 6$ genotypes are risk factor for cervical cancer development. Cancer Res 2001; 61: 608-11. 
15. Klug S.J, Wilmotte R, Santos C, et al. TP53 polymorphism, HPV infection, and risk of cervical cancer. Cancer Epidemiol Biomarkers Prev 2001; 10: 1009-12.

16. Mitra S, Misra C, Singh RK, et al. Association of specific genotype and haplotype of p53 gene with cervical cancer in India. J Clin Pathol 2005; 58: 26-31.

17. Rosenthal AN, Ryan A, Al-Jehani RM, et al. p53 codon 72 polymorphism and risk of cervical cancer in UK. Lancet 1998; 352: 871-2.

18. Ueda M, Hung YC, Terai Y, et al. Glutathione S-tranferase and p53 polymorphism in cervical carcinogenesis. Gynecol Oncol 2005; 96: 736-40.

19. Baek WK, Cho JW, Suh SI, et al. p53 codon 72 polymorphism and risk of cervical cancer in Korean women. J Korean Med Sci 2001; 15: 65-7.

20. Ishida WS, Yuenyao P, Tassaneeyakul W, et al. Selected risk factors, human papillomavirus infection and the p53 codon 72 polymorphism in patients with squamous intraepithelial lesions in Northeastern Thailand. As Pas J Cancer Prev 2006; 7: 113-8.

21. Madeleine MM, Shera K, Schwartz SM, et al. The p53 Arg72 Pro polymorphism, human papillomavirus and invasive squamous cell cervical cancer. Cancer Epidemiol Biomarkers Prev 2000; 9: 225-7.

22. Duin MV, Snijders PJ, Vossen MT, et al. Analysis of human papillomavirus type $16 \mathrm{E} 6$ variants in relation to $\mathrm{p} 53$ codon 72 polymorphism genotypes in cervical carcinogenesis. J General Virol 2000; 81: 317-25.

23. Tenti P, Vesentini N, Spaudo MR, et al. p53 codon 72 polymorphism does not affect the risk of cervical cancer in patients from Nothern Italy. Cancer Epidemiol Biomarkers Prev 2000; 9: 435-8.
24. Dybikowska A, Dettlaff A, Konopa K et al. p53 codon 72 in cervical cancer patients and healthy women from Poland. Act Biochim Polonica 2000; 47: 1179-82.

25. Yamashita T, Yaginuma Y, Saitoh Y, et al. Codon 72 polymorphism of p53 as a risk factor for patients with human papillomavirus-associated squamous intraepithelial lesions and invasive cancer of the uterine cervix. Carcinogenesis 1999; 20(9): 1733-6.

26. Calhoun ES, McGovern RM, Janney CA, et al. Host genetic polymorphism analysis in cervical cancer. Clin Chem 2002; 48(8): 1218-24.

27. Reis N, Beji NK, Kilic D. Risk factors for cervical cancer; results from a hospital-based case-control study. Int J Hematol Oncol 2011; 21(3): 153-9.

28. Gandini S, Botteri E, Iodice S, et al. Tobacco smoking and cancer: a meta-analysis. Int J Canc 2008; 122: 155-64.

29. Green J, Sweetland S, Beral V, et al. Risk factors for adenocarcinoma and squamous cell carcinoma of the cervix in women aged 20-44 years: the UK national case-control study of cervical cancer. Brit J Cancer 2003; 89: 2078-86.

30. Moreno V, Bosch FX, Muñoz N, et al. Effect of oral contraceptive on risk of cervical cancer in women with human papillomavirus infection: the IARC multicentric case-control study. Lancet 2003; 359: 1085-91.

31. Plummer M, Herrero R, Franceschi S, et al. Smoking and cervical cancer: pooled analysis of the IARC multi-centric case-control study. Cancer Cause Control 2003; 14: 80514.

32. Jee SH, Won SY, Yun JE, et al. Polymorphism p53 codon 72 and invasive cervical cancer: a metaanalysis. Int $\mathrm{J} \mathrm{Ob}$ stet Gynecol 2004; 84: 301-8. 